\title{
How costly is the first prenatal clinic visit? Analysis of out-of-pocket expenditure in rural Sri Lanka - a country with free maternal health care
}

\author{
Sajaan Praveena Gunarathne ${ }^{1 *}$, Nuwan Darshana Wickramasinghe1, Thilini Chanchala Agampodi ${ }^{1}$, \\ Indika Ruwan Prasanna ${ }^{2}$ and Suneth Buddhika Agampodi ${ }^{1}$
}

\begin{abstract}
Background: This study aimed to determine the magnitude of and factors associated with out-of-pocket expenditure (OOPE) during the first prenatal clinic visit among pregnant women in Anuradhapura district, Sri Lanka, which provides free maternal healthcare.

Methods: The study design was a cross-sectional study, and the study setting was 22 Medical Officers of Health $(\mathrm{MOOH})$ areas in Anuradhapura District, Sri Lanka. Data of 1389 pregnant women were analyzed using descriptive statistics and non-parametric tests.

Results: The mean OOPE of the first prenatal clinic visit was USD 8.12, which accounted for 2.9 and $4.5 \%$ of the household income and expenditure, respectively. Pregnant women who used only government-free health services (which are free of charge at the point of service delivery) had an OOPE of USD 3.49. A significant correlation was recorded between household expenditure $\left(r_{s}=0.095, p=0.002\right)$ and the number of pregnancies $\left(r_{s}=-0.155, p<\right.$ $0.001)$ with OOPE. Education level less than primary education is positively contributed to OOPE $(p<0.05)$, and utilizing government-free maternal health services lead to a decrease in the OOPE for the first prenatal clinic visit $(p<0.05)$.

Conclusion: Despite having free maternal services, the OOPE of the first prenatal clinic visit is high in rural Sri Lanka. One-fifth of pregnant women utilize private health services, and pregnant women who used only government-free maternal health services also spend a direct medical cost for medicines/micronutrient supplements.
\end{abstract}

Keywords: First prenatal clinic visit, Free health, Out-of-pocket expenditure, Pregnancy, Rajarata pregnancy cohort

\section{Background}

The concept of out-of-pocket expenditure (OOPE) on health care refers to the payments made by individuals and families for medical services [1] which is widely

\footnotetext{
* Correspondence: sajaanpraveen7@gmail.com

'Department of Community Medicine, Faculty of Medicine and Allied Sciences, Rajarata University of Sri Lanka, Saliyapura 50008, Sri Lanka Full list of author information is available at the end of the article
}

defined as 'direct payment for the cost of care' [2-4]. The World Bank defines OOPE as 'any direct payout by households, including gratuities and in-kind payments, to health care providers of pharmaceuticals, therapeutic appliances, and other goods and services whose primary intent is to contribute to the restoration or enhancement of the health status of individuals or population groups' [5-8]. OOPE is considered a vital issue in the global

(c) The Author(s). 2021 Open Access This article is licensed under a Creative Commons Attribution 4.0 International License, which permits use, sharing, adaptation, distribution and reproduction in any medium or format, as long as you give appropriate credit to the original author(s) and the source, provide a link to the Creative Commons licence, and indicate if changes were made. The images or other third party material in this article are included in the article's Creative Commons licence, unless indicated otherwise in a credit line to the material. If material is not included in the article's Creative Commons licence and your intended use is not permitted by statutory regulation or exceeds the permitted use, you will need to obtain permission directly from the copyright holder. To view a copy of this licence, visit http://creativecommons.org/licenses/by/4.0/. The Creative Commons Public Domain Dedication waiver (http://creativecommons.org/publicdomain/zero/1.0/) applies to the data made available in this article, unless otherwise stated in a credit line to the data. 
health agenda, as it impedes enhancing the population health most effectively under the society's available resources and competing needs [9].

OOPE exerts its negative consequences at the individual, family, community, and national levels [10]. OOPE on health reported as a leading factor in maternal mortality $[8,11,12]$, and countries with high OOPE report a higher maternal mortality ratio $[8,11]$. Poverty, indebtedness, and unbearable household budget due to the catastrophic health expenditures events $[9,13,14]$, changing the household consumption behavior [15], misuse of health care resources, reducing utilization of health care $[10,16-22]$, barriers to accessing health care facilities $[13,16,23,24]$ are some of the other implications [10]. Further, the failure of the aims in the health care system is caused by high OOPE, especially in the countries which have imposed free health facilities at the time of service delivery $[13,15,16,23,25]$. Also, high OOPE is a barrierto achieve global health-related goals Universal Health Coverage [4] and the Sustainable Development Goals (SDGs)-goal 3, and Good Health and Wellbeing [26, 27].

The influence of OOPE is further highlighted in the sub-sectors of essential health care, such as in the provision of maternal health services [28, 29]. Generally, OOPE in maternal health is referred to all the direct monetary expenditures incurred by a woman or her family during the pregnancy $[25,30]$. The OOPE in maternal health can divide into direct medical expenses and direct non-medical expenses.

Direct medical OOPE includes the consultation cost, laboratory tests, treatments, drugs, and consumables. It also includes charges for admission, hospital stay, investigations, and treatment and management [10]. Direct non-medical OOPE is comprised of the cost of traveling, food and lodging of the pregnant mother or family members/accompanying person, accommodation, and cost for servant/maid for household work [10, 14, 15]. In addition, informal payment is considered one of the major direct non-medical payments in developing countries [31-34]. The informal payments are made to receive quality care, avoid waiting in the queue, or receive other health care [32]. High OOPE is a barrier to affordability and accessibility creating inequities in maternal health $[28,29]$. Studies performed in low and middleincome countries (LMICs) such as India [35], Pakistan [36], Zambia [37], and Ghana [38] revealed that OOPE is a significant barrier to optimal maternal care.

Sri Lanka exerts free government health services since the early 1900s [39]. The country accommodates free health services by allocating an annual average budget of around 163,079.6 million rupees during the last 3 years, which accounted for $1.6 \%$ of the gross domestic product in 2019 [40]. However, it is reported as OOPE accounts for more than $35 \%$ of current health expenditure, which has remained from 2007 to 2017 [41, 42]. At present, Sri Lankan maternal health services are well developed and accessed by pregnant women via the public (to a more considerable extent) and the private health system. However, over-medicalization is a significant problem in the Sri Lankan maternal health care service provision, which is in the fourth phase of the obstetric transition $[39,43]$.

Sri Lanka is a leading country among the LMICs when considering the SDG targets related to maternal and child health. This country has a unique public health system delivering maternal care through a wellestablished network of primary health care officers. This is unique because it provides domiciliary care and clinicbased service free of charge through grass-root level health officers Public Health Midwives (PHMM). Sri Lankan health system cover $95 \%$ of pregnant women through a well-established pregnancy registration system [44]. However, there is a lack of evidence in terms of OOPE in maternal health in Sri Lanka, and all the available evidence on OOPE was related to other aspects of health care. Further, the evidence-based OOPE in its special events (clinic visits, health care seeking for maternal morbidities and other special health-seeking, etc.) is lacking. A detailed assessment of OOPE on maternal care in a country with high health system standards would be valuable in generating global level evidence on the manifestations of OOPE. .

This study aimed to explore the magnitude and associated factors of OOPE among pregnant women during the first prenatal clinic visit in rural Sri Lanka. Therefore, we explored the following two questions that remain unanswered in the rural Sri Lankan context: What are the magnitudes of OOPE of the first prenatal clinic visit of rural Sri Lanka? What are the associated factors of OOPE in the first prenatal clinic visit?

\section{Methods}

This study was a part of a large cohort survey of pregnant women living in the Anuradhapura district, Sri Lanka, Rajarata Pregnancy Cohort (RaPCo). The RaPCo study is a prospective cohort study, mainly conducted to identify the implications of socio-economic, demographic characteristics, and maternal mental health status on pregnancy and newborn outcomes [44]. An economic evaluation under the RaPCo study has been conducted to examine the economic burden of OOPE, productivity loss/cost of pregnant women, and the impact of the COVID-19 pandemic on the household economy of pregnant women in rural Sri Lanka [7]. The complete economic evaluation was a follow-up study that was carried out throughout the pregnancy period. The present study is a part of the sub-component 
(economic burden of OOPE) of the economic evaluation of the RaPCo study $[7,44]$.

\section{Study design and setting}

The present study is a cross-sectional study in a cohort of pregnant women enrolled in the RaPCo study during the first trimester and held in Anuradhapura, the largest district in Sri Lanka $\left(7179 \mathrm{~km}^{2}\right)$. The recorded total population is 902,930 , and $92.7 \%$ of them live in rural areas. Agriculture is their primary source of revenue with a median household income of LKR 41,629.00 (United States Dollar [USD] 285.91) per month [45], and Sinhalese are the leading ethnic group (90.7\%) [46]. In the Anuradhapura district, health expenditure consists of $42 \%$ private, $22 \%$ central government, and $36 \%$ other government sources $[47,48]$.

The services for pregnant women are offered via the Medical Officer of Health $(\mathrm{MOH})$, and the Anuradhapura district has $22 \mathrm{MOH}$ areas. The district is divided into 275 public health midwife (PHM) areas, with each PHM area having a population of 1500-4000. The number of pregnant women registered in the area in 2015 was approximately 17,000 , and the number of live births was 15,376 [44]. The study protocol of the RaPCo has published further details on the study setting, including $\mathrm{MOH}$ areas [44].

\section{Study participants}

The study population of the RaPCo study included all pregnant women residing in the Anuradhapura district from July to September 2019 with the following eligibility criteria: first; pregnant women registered in the "pregnant mothers' register" of PHMM and visiting antenatal field clinics in the Anuradhapura district, second; permanent residence in the Anuradhapura district for the year ahead, third; period of amenorrhea (POA)/ gestational age (GA) less than 12 weeks by the time of recruitment. Pregnant women planning to leave the study area for or after childbirth and pregnant women with uncertain dates were excluded from the study. Pregnant women were recruited with the assistance of the PHMM of each $\mathrm{MOH}$ area at the special clinics organized by the cooperation of the research team and the divisional level public health officers. All $\mathrm{MOOH}$ and PHMM were informed of the study objectives and the data collection process.

Considering the sensitive nature of data that included the in-depth financial details collected for this investigation, only the women who volunteered to provide such information were chosen to participate in this study. Written consent was sorted from the participants, and ethical and administrative clearance was obtained before recruitment.

\section{Definitions and measures}

The OOPE associated with the first prenatal clinic visit, known as the 'booking visit,' was assessed in detail during this study. In Sri Lankan maternal health services, the 'booking visit' is the first clinic visit by a pregnant mother. These services are freely available to any expectant mother throughout the country's public health sector [49]. During this visit, all pregnant women are examined by a medical officer, and generally, all relevant investigations are done in the government healthcare sector, free-of-charge, under several objectives ${ }^{1}$ [49]. Private health services are also available, where pregnant women can channel a specialist in the private sector. This visit includes the cost of consultation, laboratory investigations, and medicines/supplements.

To assess the OOPE associated with the booking visit, the OOPE was computed under two main categories: direct medical cost and direct non-medical cost.

- Direct medical cost (cost for consultation and cost for medicines/micronutrient supplements)

- Direct non-medical cost (cost for traveling, costs for foods and refreshments, the cost for accompanying person, and other costs)

All recruited women were provided with facilities for basic investigations free-of-charge in the RaPCo study; hence, this analysis did not include any laboratory investigation cost.

\section{Data collection}

The study instruments included an intervieweradministered questionnaire on socio-demographic and household economic data and a self-administered questionnaire on pregnancy-related economic data. The study tools were pre-tested and edited according to the pre-tested sample's answers, comments, and suggestions. Both surveys were conducted during the first trimester.

The participants were provided with the selfadministered questionnaire to be filled at home. In addition to explaining how to complete the selfadministered questionnaire, an information leaflet was attached, stating the study's overall objective and

\footnotetext{
${ }^{1} 1$. To the provisional establishment of pregnancy (either clinically/ with laboratory testing)

2. To assess medical and obstetric risk factors and take necessary actions

3. To assess the psychological/nutritional status and take necessary actions

4. To provide micronutrient supplements (Folic acid, iron folate,

Vitamin C, and calcium supplementation)

5. To provide the necessary care and health promotion

6. Screening for anemia, syphilis, and testing for blood group and Rh

7. Check for dental conditions and appropriate referral

8. Heart examination to identify heart diseases [49].
} 
instructions to complete- to improve the data credibility. Pregnant women were asked to keep pregnancyrelated expenditures in a diary before filling the questionnaire, and telephone reminders were made to complete the questionnaires within 2 weeks.

\section{Data analysis}

Data were manually entered in Microsoft Office Excel and imported into SPSS for analysis. Data entry was followed by data cleaning to identify incompatible entries and missing data. All the incompatible entries were checked manually before eliminating them from the database. The Statistical Package for Social Sciences (IBM SPSS Statistics 21) was used for data analysis.

All the income and expenditure-related data were collected in Sri Lankan Rupees (LKR). In the data management stage, the monitory values were converted from LKR to United States Dollar (USD), according to the rates of July 2019, i.e., USD 1 = LKR 176.38 [50].

Sample characteristics were reported using descriptive statistical measures; mean (SD), median (IQR), mode, and frequencies. Descriptive statistics helped to summarize the magnitude of OOPE. Further, we presented the proportion of OOPE over household income and expenditure. The total OOPE was presented in terms of different income quintiles. The OOPE occurred for pregnant women who used private medical care and government-free health facilities (which are free of charge at the point of service delivery) using descriptive statistical measures. To analyze the associated factors, we performed the Kolmogorov-Smirnov test to assess the distribution of the variable OOPE. The test result disclosed the data are not normally distributed $(p<$ $0.05)$. Therefore, we used non-parametric tests to assess statistical significance and conducted the Mann-Whitney $\mathrm{U}$ test and the Kruskal-Wallis $\mathrm{H}$ test for the categorical variables. The continuous variables were analyzed via the Spearman Rank Correlation. Further, we performed a Multiple Linear Regression Model (MLRM) to find the impact of associated factors on OOPE. The study sample used in the MLRM is adequate to get an excellent prediction according to the sample Size recommendations at Selected Levels of squared population multiple correlation coefficients (R Square) for performing MLRM [51].

\section{Results}

\section{Sample characteristics}

All the pregnant women $(n=3367)$ of the RaPCo study were invited for the present study and 1389 pregnant women were participated with a response rate of $41.3 \%$. All the sample characteristics were presented in Table 1. The mean (Standard Deviation [SD]) age of the participants was 28.3 (5.5) years. The sample's leading ethnic group was Sinhalese $(n=1184,89.8 \%)$, and the main religion was Buddhism ( $n=1172,88.8 \%)$. Most pregnant women have studied up to Grade $11(n=641,48.8 \%)$. In the sample, $78.8 \%$ of pregnant women were housewives; not engage in any income-generating activities $(n=$ $1094)$, and among the employed group, $38.4 \%(n=112)$ were working in the government sector.

Most pregnant women were in their first pregnancy $(n=510,36.7 \%)$. The mean (SD) duration until pregnancy confirmation was 6.4 (2.7) weeks. Public transport was the primary transportation mode for accessing health care facilities $(n=895,68.9 \%)$, and most pregnant women $(n=784,61.3 \%)$ preferred to use government health facilities.

The mean (SD) and the median (Inter Quartile Range [IQR]) monthly income of the employed pregnant women were USD 154.82 (126.20) and USD 141.74 (85.04-203.54), respectively. The mean (SD) of the monthly household income and the expenditure were USD 283.24 (220.99) and USD 184.81 (119.20), respectively. The corresponding median (IQR) values were USD 226.78 (170.09-323.17) and USD 163.00 (111.12230.47).

The magnitude of OOPE for the first prenatal clinic visit Breakdown of OOPE- direct medical and non-medical cost The mean (SD) OOPE for the first prenatal clinic visit was USD 8.12 (16.47). Compared to monthly household income and expenditure, the total OOPE for the first prenatal clinic visit was approximately $2.9 \%$ of revenue and $4.5 \%$ of the spending. This was calculated by assuming that the monthly household income and the spending do not change in the short run since a shorter period was considered for the present study.

The breakdown of OOPE in the first prenatal clinic visit was reported in terms of the direct medical and direct non-medical cost and according to the health facility used in Table 3.

The mean (SD) direct medical OOPE of the first prenatal clinic visit was USD 16.26 (20.45), and it was 68.2\% of the total OOPE; thus, it is almost twice the value of the direct non-medical cost. Among the direct medical expense, the cost share for consultation (Mean $=$ USD 16.41, $\mathrm{SD}=17.10$ ) was the highest, followed by the cost for medicines/micronutrient supplements $($ Mean $=$ USD 7.72, $\mathrm{SD}=10.22$ ).

Figure 1 presents the breakdown of all expenditures and the composition of direct medical and direct nonmedical costs during the first trimester of the pregnant women in the sample. It highlights that the costs for consultation had the highest proportion of OOPE among all cost categories and accounted for $42.1 \%$. In contrast, the cost for the accompanying person is the minor share, $3.5 \%$ of the total OOPE. 
Table 1 Characteristics of the surveyed sample

\begin{tabular}{|c|c|c|c|}
\hline Characteristics/measurement & & $\mathrm{n}$ & $\begin{array}{l}\text { Percentage } \\
\text { (\%)/statistics }\end{array}$ \\
\hline \multirow[t]{5}{*}{ Ethnicity } & Sinhalese & 1184 & $89.8 \%$ \\
\hline & Tamil & 6 & $0.4 \%$ \\
\hline & Moor & 124 & $9.4 \%$ \\
\hline & Malay & 1 & $0.1 \%$ \\
\hline & Other & 4 & $0.3 \%$ \\
\hline \multirow[t]{4}{*}{ Religion } & Buddhist & 1172 & $88.8 \%$ \\
\hline & Catholic/Christian & 18 & $1.4 \%$ \\
\hline & Hindu & 4 & $0.3 \%$ \\
\hline & Islam & 126 & $9.5 \%$ \\
\hline \multirow[t]{5}{*}{ Education level (in school) } & Less than primary education $(<$ grade 5 ) & 10 & $0.8 \%$ \\
\hline & Up to primary education & 2 & $0.2 \%$ \\
\hline & Between grades 5 to 11 & 116 & $8.8 \%$ \\
\hline & Up to ordinary level examination $(\mathrm{O} / \mathrm{L})$ & 641 & $48.8 \%$ \\
\hline & Up to advanced level examination (A/L) & 544 & $41.4 \%$ \\
\hline \multirow[t]{2}{*}{ Employment status } & Employed & 295 & $21.2 \%$ \\
\hline & $\begin{array}{l}\text { Housewives (do not engage in any income-generating } \\
\text { activities) }\end{array}$ & 1094 & $78.8 \%$ \\
\hline \multirow[t]{4}{*}{ Employment sector } & Government & 112 & $38.4 \%$ \\
\hline & Semi-government & 15 & $5.1 \%$ \\
\hline & Private & 79 & $27.1 \%$ \\
\hline & Other & 86 & $29.4 \%$ \\
\hline \multirow[t]{2}{*}{ Age (in years) } & Mean (SD) & 1389 & $28.3(5.5)$ \\
\hline & Median (IQR) & & $28(25-32)$ \\
\hline \multirow[t]{6}{*}{ No. of pregnancies } & Mean (SD) & 1389 & $2.1(1.1)$ \\
\hline & Median (IQR) & & $2(1-3)$ \\
\hline & 1 & 510 & $36.7 \%$ \\
\hline & 2 & 416 & $29.9 \%$ \\
\hline & 3 & 335 & $24.1 \%$ \\
\hline & 4 and more & 128 & $9.3 \%$ \\
\hline \multirow{7}{*}{$\begin{array}{l}\text { Period of Amenorrhea (POA)-at the time of recruitment (in } \\
\text { weeks) }\end{array}$} & Mean (SD) & 1389 & $9.2(3.1)$ \\
\hline & Median (IQR) & & $9(7-10)$ \\
\hline & $<6$ weeks & 174 & $13.0 \%$ \\
\hline & $6-8$ weeks & 484 & $36.2 \%$ \\
\hline & $8-10$ weeks & 372 & $27.8 \%$ \\
\hline & $10-12$ weeks & 173 & $12.9 \%$ \\
\hline & $>12$ weeks & 135 & $10.1 \%$ \\
\hline \multirow[t]{2}{*}{ Mother's monthly income (USD) } & Mean (SD) & 295 & $154.82(126.20)$ \\
\hline & Median (IQR) & & $141.74(85.04-203.54)$ \\
\hline \multirow[t]{2}{*}{ Monthly household income (USD) } & Mean (SD) & 1389 & $283.24(220.99)$ \\
\hline & Median (IQR) & & $226.78(170.09-323.17)$ \\
\hline \multirow[t]{2}{*}{ Monthly household expenditure (USD) } & Mean (SD) & 1362 & $184.81(119.20)$ \\
\hline & Median (IQR) & & $163.00(111.12-230.47)$ \\
\hline
\end{tabular}




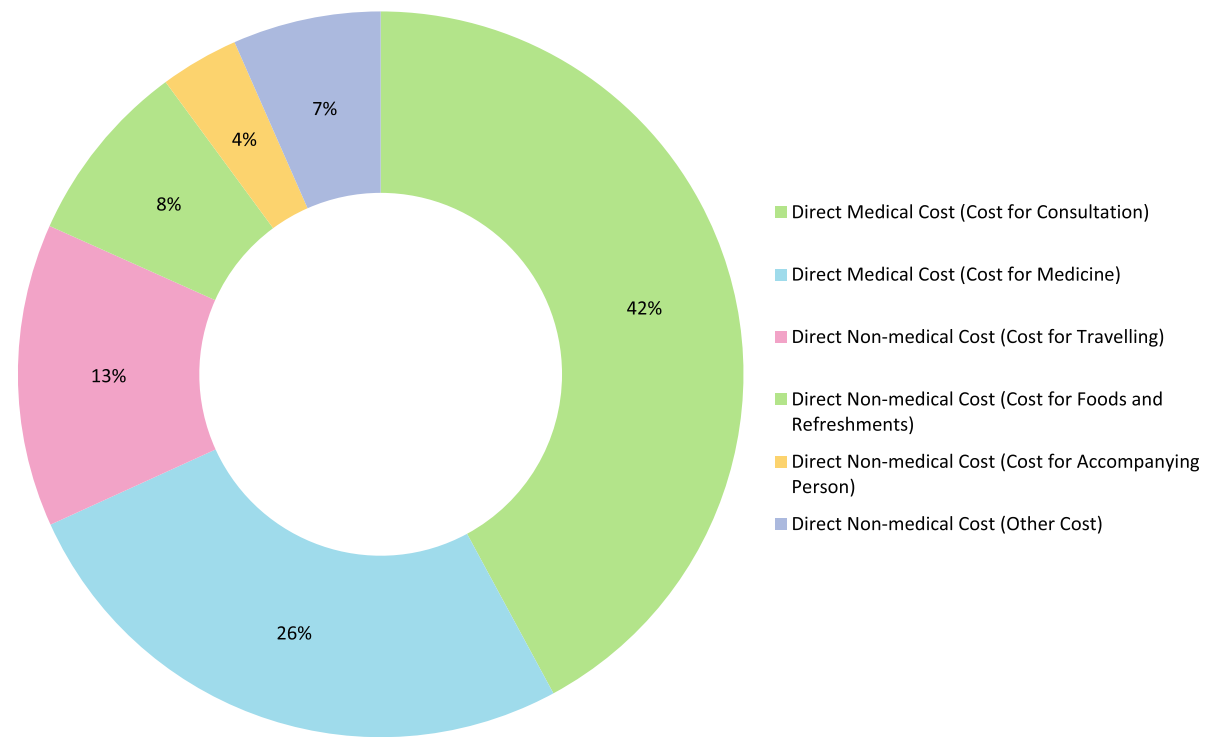

Fig. 1 Breakdown of OOPE

Among the surveyed sample, 343 pregnant women (24.7\%) financed health care by spending money kept for their everyday transaction purposes, and 191 pregnant women (13.8\%) have withdrawn money from their savings. Only one mother from the entire study sample owned a health insurance policy, while others were financed by informal loans with high-interest rates $(n=$ $14,1.0 \%)$ and selling assets such as jewelry $(n=7,0.5 \%)$.

\section{OOPE among different income quintiles}

Table 2 presents the OOPE among different income quintiles.

The lowest income groups' (< USD 170.08 and USD 170.09-215.44) OOPE for the first prenatal clinic visit were USD 8.79 and USD 10.30, 4.4 and $4.5 \%$ monthly household income, respectively.

Among the pregnant women in the lowest income quintile, $61.3 \%$ of expenditure was direct medical expenditure; the mean (SD) OOPE were USD 14.56 (7.41) for consultation and USD 5.64 (9.20) for medicines, which accounted for 37.9 and $23.4 \%$ of total OOPE for the first prenatal clinic visit. The direct non-medical expenditure accounted for $38.7 \%$ within the lowest income quintile.

\section{OOPE in government-free health services and private health services}

Table 3 indicates the direct medical and direct nonmedical expenditure incurred for the first prenatal clinic visit among pregnant women who used only government-free health services and private health services. The majority $(n=1100,79.2 \%)$ in the study sample used only the government's free maternal health services. There is a statistically significant difference in direct non-medical OOPE between pregnant women who used only the government's free health services and those who used private health services $(\mathrm{U}=52,890.0,|z|$ $=7.9$ ). Even among the pregnant women who used free maternal health services, the OOPE was USD 3.49 (SD = 6.53). It included all the direct non-medical expenditures and costs for medicines/micronutrient supplements as the direct medical cost. The mean (SD) direct medical

Table 2 OOPE among different income quintiles

\begin{tabular}{|c|c|c|c|c|c|c|}
\hline \multirow{2}{*}{\multicolumn{2}{|c|}{ Income Quintile (USD) }} & \multicolumn{2}{|l|}{ OOPE (USD) } & \multirow[t]{2}{*}{ n (\%) } & \multirow{2}{*}{$\begin{array}{l}\text { OOPE on } \\
\text { household } \\
\text { Income } \\
\text { (\%) }\end{array}$} & \multirow{2}{*}{$\begin{array}{l}\text { OOPE on } \\
\text { household } \\
\text { cost (\%) }\end{array}$} \\
\hline & & Mean (SD) & Median (IQR) & & & \\
\hline 1 & $<170.08$ & $8.79(13.83)$ & $2.83(1.13-11.06)$ & $383(27.6 \%)$ & $4.4 \%$ & $3.6 \%$ \\
\hline 2 & $170.09-215.44$ & $10.30(13.76)$ & $3.12(1.13-17.29)$ & $192(13.8 \%)$ & $4.5 \%$ & $5.1 \%$ \\
\hline 3 & $215.45-255.13$ & $15.28(24.13)$ & $3.40(1.13-21.97)$ & 277 (19.9\%) & $4.8 \%$ & $5.9 \%$ \\
\hline 4 & $255.14-368.52$ & $10.31(18.86)$ & $2.83(0.85-11.34)$ & $282(20.3 \%)$ & $2.5 \%$ & $3.9 \%$ \\
\hline 5 & $>368.53$ & $10.12(18.32)$ & $3.01(1.13-16.44)$ & 255 (18.4) & $1.3 \%$ & $4.1 \%$ \\
\hline
\end{tabular}


Table 3 OOPE of the first prenatal clinic visit (for government-free and private health facilities)

\begin{tabular}{|c|c|c|c|c|c|c|c|c|c|c|}
\hline \multicolumn{2}{|l|}{ Cost Category } & \multicolumn{3}{|c|}{$\begin{array}{l}\text { The cost incurred using only } \\
\text { government free health care } \\
\text { (USD) }\end{array}$} & \multicolumn{3}{|c|}{$\begin{array}{l}\text { The cost incurred in using } \\
\text { private health care (USD) }\end{array}$} & \multicolumn{3}{|c|}{ OOPE of the total sample } \\
\hline & & $\begin{array}{l}\mathrm{n} \\
\text { (\% of the } \\
\text { sample) }\end{array}$ & $\begin{array}{l}\text { Mean } \\
\text { (SD) }\end{array}$ & $\begin{array}{l}\text { Median } \\
\text { (IQR) }\end{array}$ & $\begin{array}{l}\mathrm{n} \\
\text { (\% of the } \\
\text { sample) }\end{array}$ & $\begin{array}{l}\text { Mean } \\
\text { (SD) }\end{array}$ & $\begin{array}{l}\text { Median } \\
\text { (IQR) }\end{array}$ & $\begin{array}{l}\mathrm{n} \\
\text { (\% of the } \\
\text { sample) }\end{array}$ & $\begin{array}{l}\text { Mean } \\
\text { (SD) }\end{array}$ & $\begin{array}{l}\text { Median } \\
\text { (IQR) }\end{array}$ \\
\hline \multirow[t]{2}{*}{$\begin{array}{l}\text { Direct Medical } \\
\text { OOPE }\end{array}$} & Cost for consultation & - & - & - & $289(20.8 \%)$ & $\begin{array}{l}16.41 \\
(17.10)\end{array}$ & $\begin{array}{l}14.74 \\
(11.34- \\
17.01)\end{array}$ & $289(20.8 \%)$ & $\begin{array}{l}16.41 \\
(17.10)\end{array}$ & $\begin{array}{l}14.74 \\
(11.34- \\
17.01)\end{array}$ \\
\hline & $\begin{array}{l}\text { Cost for medicine/ } \\
\text { micronutrient supplements }\end{array}$ & $189(13.6 \%)$ & $\begin{array}{l}2.82 \\
(6.17)\end{array}$ & $\begin{array}{l}0.85 \\
(0.57- \\
2.55)\end{array}$ & $198(14.3 \%)$ & $\begin{array}{l}12.27 \\
(11.16)\end{array}$ & $\begin{array}{l}9.07(3.97- \\
17.01)\end{array}$ & $387(27.8 \%)$ & $\begin{array}{l}7.72 \\
(10.22)\end{array}$ & $\begin{array}{l}2.83(0.62- \\
11.34)\end{array}$ \\
\hline \multirow[t]{4}{*}{$\begin{array}{l}\text { Direct non- } \\
\text { medical OOPE }\end{array}$} & Cost for travelling & $521(37.5 \%)$ & $\begin{array}{l}1.58 \\
(2.80)\end{array}$ & $\begin{array}{l}0.85 \\
(0.57- \\
1.70)\end{array}$ & $172(12.4 \%)$ & $\begin{array}{l}4.05 \\
(5.84)\end{array}$ & $\begin{array}{l}1.90(1.13- \\
4.40)\end{array}$ & $693(49.9 \%)$ & $\begin{array}{l}2.19 \\
(3.93)\end{array}$ & $\begin{array}{l}1.13(0.57- \\
1.7)\end{array}$ \\
\hline & Food and refreshment & $440(31.7 \%)$ & $\begin{array}{l}1.27 \\
(1.30)\end{array}$ & $\begin{array}{l}1.13 \\
(0.57- \\
1.56)\end{array}$ & $154(11.1 \%)$ & $\begin{array}{l}2.45 \\
(2.86)\end{array}$ & $\begin{array}{l}1.70(1.13- \\
2.83)\end{array}$ & $594(42.8 \%)$ & $\begin{array}{l}1.58 \\
(1.90)\end{array}$ & $\begin{array}{l}1.13(0.57- \\
1.70)\end{array}$ \\
\hline & $\begin{array}{l}\text { Cost for accompanying } \\
\text { person }\end{array}$ & $204(14.7 \%)$ & $\begin{array}{l}1.22 \\
(1.47)\end{array}$ & $\begin{array}{l}0.85 \\
(0.57- \\
1.13)\end{array}$ & $58(4.2 \%)$ & $\begin{array}{l}2.44 \\
(2.41)\end{array}$ & $\begin{array}{l}1.70(1.13- \\
2.83)\end{array}$ & $262(18.9 \%)$ & $\begin{array}{l}1.49 \\
(1.79)\end{array}$ & $\begin{array}{l}0.85(0.57- \\
1.70)\end{array}$ \\
\hline & Other costs & $156(11.2 \%)$ & $\begin{array}{l}2.94 \\
(4.71)\end{array}$ & $\begin{array}{l}0.71 \\
(0.57- \\
3.72)\end{array}$ & $32(2.3 \%)$ & $\begin{array}{l}8.73 \\
(12.16)\end{array}$ & $\begin{array}{l}2.83(0.88- \\
12.76)\end{array}$ & $188(13.5 \%)$ & $\begin{array}{l}3.93 \\
(6.90)\end{array}$ & $\begin{array}{l}0.85(0.57- \\
5.66)\end{array}$ \\
\hline Total (OOPE) & & $\begin{array}{l}1100 \\
(79.2 \%)\end{array}$ & $\begin{array}{l}3.49 \\
(6.53)\end{array}$ & $\begin{array}{l}1.70 \\
(0.85- \\
3.54)\end{array}$ & $\begin{array}{l}289 \\
(20.8 \%)\end{array}$ & $\begin{array}{l}29.99 \\
(24.09)\end{array}$ & $\begin{array}{l}24.38 \\
(17.31- \\
34.58)\end{array}$ & $\begin{array}{l}1389 \\
(100 \%)\end{array}$ & $\begin{array}{l}8.12 \\
(16.47)\end{array}$ & $\begin{array}{l}2.95 \\
(1.13- \\
16.02)\end{array}$ \\
\hline
\end{tabular}

OOPE in terms of cost for medicines/micronutrient supplements for the first prenatal clinic visit was USD 2.82 (6.17).

Figure 2 illustrates the share of different cost categories on OOPE according to the health care facilities used. All the direct medical costs were high among the pregnant women who used government and private health services, and the share of all direct non-medical costs was high among pregnant women who used government health facilities only.

Factors associated with OOPE

Table 4 demonstrates the associated factors of OOPE for the first prenatal clinic visit. There is a statistically significant positive correlationbetween OOPE and monthly household expenditure, and a statistically significant

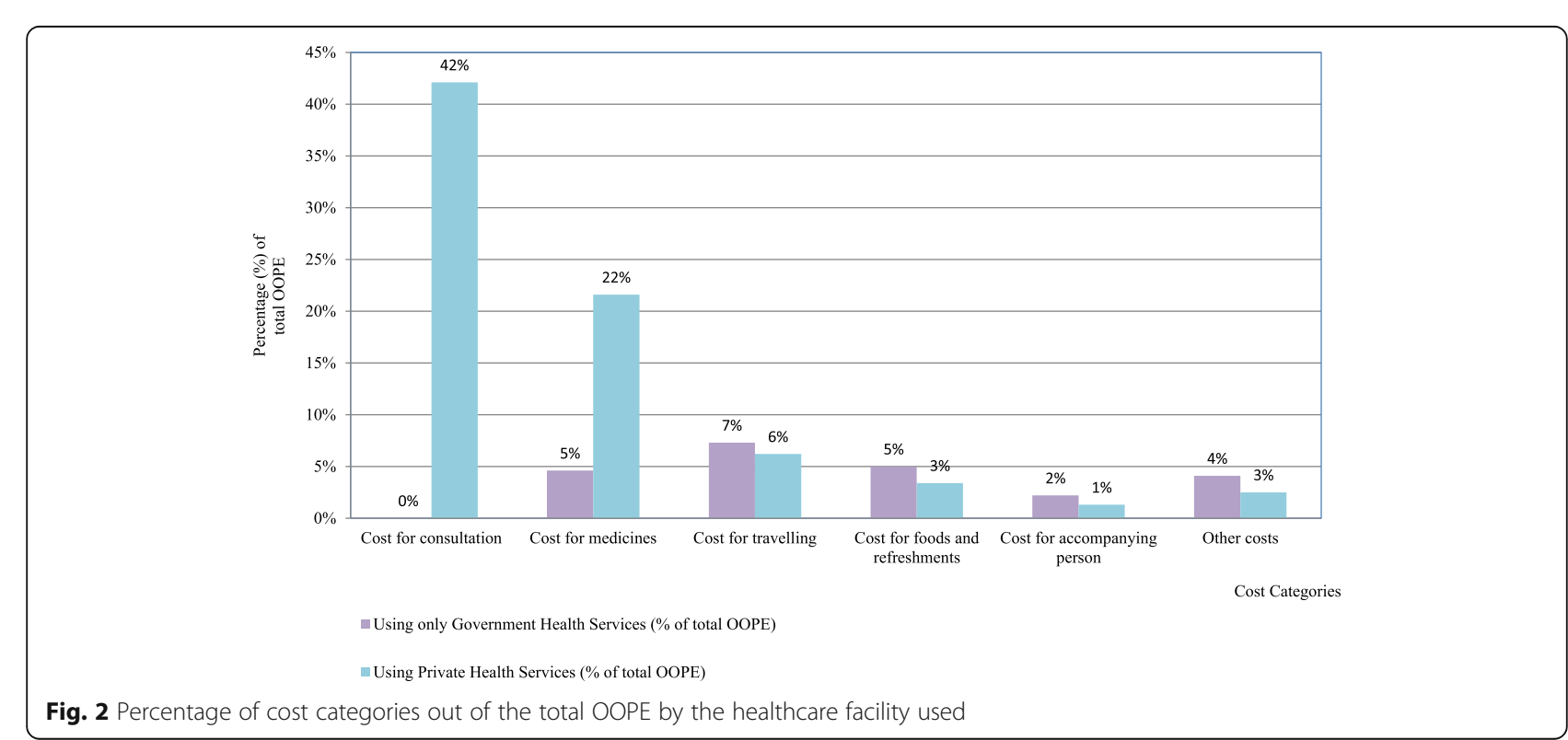


Table 4 Associated factors of OOPE

\begin{tabular}{|c|c|c|c|c|c|}
\hline Performed Test & Variable & Groups Tested & $\begin{array}{l}\text { Mean (SD) } \\
\text { OOPE [USD] }\end{array}$ & $\begin{array}{l}\text { Median (IQR) } \\
\text { OOPE [USD] }\end{array}$ & $\begin{array}{l}\text { Test } \\
\text { Statistics }\end{array}$ \\
\hline \multirow[t]{2}{*}{$\begin{array}{l}\text { Mann-Whitney U } \\
\text { Statistics }\end{array}$} & Employment status & Employed $\left(n_{1}=295\right)$ & $13.64(12.63)$ & $\begin{array}{l}14.17(1.13- \\
19.84)\end{array}$ & $\begin{array}{l}U=92,939.5 \\
(|z|=0.263)\end{array}$ \\
\hline & & $\begin{array}{l}\text { Housewives (not engage in any income- } \\
\text { generating activities) }\left(n_{2}=1094\right)\end{array}$ & $17.02(22.16)$ & $\begin{array}{l}14.46(1.42- \\
23.96)\end{array}$ & \\
\hline \multirow[t]{20}{*}{$\begin{array}{l}\text { Kruskal-Wallis H } \\
\text { Test }\end{array}$} & Employment sector & Government $\left(n_{1}=112\right)$ & $12.61(11.61)$ & $\begin{array}{l}13.61(0.85- \\
18.71)\end{array}$ & $\begin{array}{l}x^{2}=4.266 \\
(p=0.234)\end{array}$ \\
\hline & & Semi-government $\left(n_{2}=15\right)$ & $10.09(7.37)$ & $8.5(5.67-16.44)$ & \\
\hline & & Private $\left(\mathrm{n}_{3}=79\right)$ & $17.20(13.94)$ & $17.01(3.4-24.66)$ & \\
\hline & & Other $\left(n_{4}=86\right)$ & $12.56(13.08)$ & $\begin{array}{l}11.34(0.91- \\
17.38)\end{array}$ & \\
\hline & Ethnicity & Sinhalese $\left(n_{1}=1184\right)$ & $16.32(21.18)$ & $\begin{array}{l}14.17(1.13- \\
22.68)\end{array}$ & $\begin{array}{l}x^{2}=1.926 \\
(p=0.588)\end{array}$ \\
\hline & & Tamil $\left(\mathrm{n}_{2}=6\right)$ & $12.57(9.21)$ & $\begin{array}{l}17.01(9.50- \\
20.98)\end{array}$ & \\
\hline & & Moor $\left(n_{3}=124\right)$ & $13.73(13.49)$ & $\begin{array}{l}12.47(0.85- \\
20.98)\end{array}$ & \\
\hline & Religion & Buddhist $\left(\mathrm{n}_{1}=1172\right)$ & $16.37(21.24)$ & $\begin{array}{l}14.17(1.13- \\
22.68)\end{array}$ & $\begin{array}{l}x^{2}=1.944 \\
(p=0.584)\end{array}$ \\
\hline & & Catholic/Christian $\left(\mathrm{n}_{2}=18\right)$ & $9.30(7.50)$ & $\begin{array}{l}12.76(1.98- \\
14.17)\end{array}$ & \\
\hline & & Hindu $\left(n_{3}=4\right)$ & $17.86(1.20)$ & $\begin{array}{l}17.86(17.01- \\
18.71)\end{array}$ & \\
\hline & & Islam $\left(n_{4}=126\right)$ & $13.73(13.49)$ & $\begin{array}{l}12.47(0.85- \\
20.98)\end{array}$ & \\
\hline & Education level & Less than primary education $\left(n_{1}=10\right)$ & $30.62(48.49)$ & $9.78(1.00-60.24)$ & $x^{2}=3.157$ \\
\hline & & Between grade 5 to $11\left(n_{3}=116\right)$ & $17.45(13.40)$ & $\begin{array}{l}17.01(4.12- \\
22.96)\end{array}$ & \\
\hline & & Up to ordinary level $\left(n_{4}=641\right)$ & $16.28(21.84)$ & $\begin{array}{l}14.17(1.13- \\
23.39)\end{array}$ & \\
\hline & & Up to advanced level $\left(n_{5}=544\right)$ & $15.23(19.49)$ & $\begin{array}{l}14.17(1.13- \\
20.41)\end{array}$ & \\
\hline & $\begin{array}{l}\text { Period of Amenorrhea (at the } \\
\text { time of recruitment) }\end{array}$ & $<6$ weeks $\left(n_{1}=174\right)$ & $14.85(14.01)$ & $\begin{array}{l}14.17(1.13- \\
19.84)\end{array}$ & $\begin{array}{l}x^{2}=1.000 \\
(p=0.910)\end{array}$ \\
\hline & & $6-8$ weeks $\left(n_{2}=484\right)$ & $17.10(24.15)$ & $14.6(1.13-21.54)$ & \\
\hline & & $8-10$ weeks $\left(n_{3}=372\right)$ & $16.89(22.42)$ & $\begin{array}{l}14.74(1.56- \\
25.23)\end{array}$ & \\
\hline & & $10-12$ weeks $\left(n_{4}=173\right)$ & $13.41(13.28)$ & $\begin{array}{l}12.62(1.13- \\
19.84)\end{array}$ & \\
\hline & & $>12$ weeks $\left(n_{5}=135\right)$ & $15.05(16.25)$ & $\begin{array}{l}14.17(1.13- \\
20.41)\end{array}$ & \\
\hline \multirow[t]{5}{*}{$\begin{array}{l}\text { Spearman Rank } \\
\text { Correlation }\end{array}$} & Number of pregnancies ${ }^{*}$ & & & & $\begin{array}{l}r_{s}=-0.155 \\
(p=0.000)\end{array}$ \\
\hline & Age of the mother & & & & $\begin{array}{l}r_{s}=0.028 \\
(p=0.378)\end{array}$ \\
\hline & Mother's monthly income level & & & & $\begin{array}{l}r_{s}=0.012 \\
(p=0.861)\end{array}$ \\
\hline & Monthly household income & & & & $\begin{array}{l}r_{s}=-0.002 \\
(p=0.942)\end{array}$ \\
\hline & Monthly household expenditure & & & & $\begin{array}{l}r_{s}=0.095 \\
(p=0.002)\end{array}$ \\
\hline
\end{tabular}

"Reject null hypothesis: no correlation - since the $p$ values are lesser than 0.05 
negative correlation between OOPE and the number of pregnancies.

All 17 independent predictors were identified according to the evidence in the literature and purposefully and included in the MLRM at the initial stage. After the several steps, seven independent variables (Pregnant women's monthly income, monthly household expenditure, $\mathrm{MOH}$ area, Ethnicity, Religion, and the economic status due to the poverty line) were eliminated from the model to avoid the multicollinearity issue and to keep the overall significance of the model. The overall model is statistically significant $(\mathrm{F}=68.11, p<0.001)$ and has an $\mathrm{R}$-square value of 0.49 . The model does not show the autocorrelation issue as the Durbin-Watson D statistics is 2.01. Table 5 is presented the impact of predictor variables on the dependent variable OOPE.
The constant term was statistically significant, reflecting that, when all other factors are being constant, the OOPE of the first prenatal clinic visit is USD 27.76. Further, three dummies of predictor variables were statistically significant. Compared with the lowest income quintile (< USD 170.08), the middle-income group (USD 215.45-255.13) spends more of USD 2.51 as OOPE for the first prenatal clinic visit when other factors are constant. Moreover, compared with the pregnant women who had been educated up to the advanced level examination, the pregnant women who had received less than primary education (<grade 5) expended more of USD 10.89 when controlling other characteristics. In addition, pregnant women who utilize government-free maternal health services pay USD 27.09 less when compared with pregnant women who use private health services for the first prenatal clinic visit.

Table 5 MLRM for the impact of associated factors on OOPE

\begin{tabular}{|c|c|c|c|c|c|c|c|}
\hline \multirow[t]{2}{*}{ Model } & & \multirow[t]{2}{*}{$\begin{array}{l}\text { Coefficient } \\
\text { (B) }\end{array}$} & \multirow[t]{2}{*}{ t- } & \multirow[t]{2}{*}{$\begin{array}{l}P \text { - } \\
\text { value }\end{array}$} & \multicolumn{2}{|c|}{$\begin{array}{l}95.0 \% \\
\text { Confidence } \\
\text { Interval for B }\end{array}$} & \multirow{2}{*}{$\begin{array}{l}\text { Variance } \\
\text { Inflation } \\
\text { Factor } \\
\text { (VIF) }\end{array}$} \\
\hline & & & & & $\begin{array}{l}\text { Lower } \\
\text { Bound }\end{array}$ & $\begin{array}{l}\text { Upper } \\
\text { Bound }\end{array}$ & \\
\hline Constant $^{*}$ & & 27.76 & 11.698 & 0.000 & 23.10 & 32.41 & - \\
\hline Monthly household income & & $-8.605 E-6$ & -0.723 & 0.470 & 0.00 & 0.00 & 2.05 \\
\hline \multirow[t]{4}{*}{$\begin{array}{l}\text { Income quintile (compared to income quintile } 1[<\text { USD } \\
\text { 170.08]) }\end{array}$} & $\begin{array}{l}\text { Income quintile } 2 \\
\text { (USD 170.09-215.44) }\end{array}$ & 0.77 & 0.693 & 0.488 & -1.41 & 2.95 & 1.36 \\
\hline & $\begin{array}{l}\text { Income quintile } 3^{*} \\
\text { (USD 215.45-255.13) }\end{array}$ & 2.51 & 2.480 & 0.013 & 0.52 & 4.49 & 1.51 \\
\hline & $\begin{array}{l}\text { Income quintile } 4 \\
\text { (USD 255.14-368.52) }\end{array}$ & 1.52 & 1.427 & 0.154 & -0.57 & 3.61 & 1.67 \\
\hline & $\begin{array}{l}\text { Income quintile } 5 \\
\text { (> USD 368.53) }\end{array}$ & 1.52 & 1.004 & 0.315 & -1.45 & 4.48 & 3.13 \\
\hline Age of the Mother & & 0.09 & 1.510 & 0.131 & -0.03 & 0.21 & 1.05 \\
\hline $\begin{array}{l}\text { Employment status } \\
\text { (compared with the Housewives - do not engage in any } \\
\text { income generating activities) }\end{array}$ & Employed & -1.95 & -1.424 & 0.155 & -4.63 & 0.74 & 2.81 \\
\hline \multirow{2}{*}{$\begin{array}{l}\text { Sector of the employment (compared to the government } \\
\text { sector) }\end{array}$} & Semi-government & -0.45 & -0.248 & 0.804 & -3.10 & 3.10 & 2.27 \\
\hline & Private & 1.91 & 1.006 & 0.315 & -1.81 & 5.63 & 1.77 \\
\hline \multirow[t]{4}{*}{$\begin{array}{l}\text { Educational level (compared with the 'up to advanced } \\
\text { level examination') }\end{array}$} & $\begin{array}{l}\text { Less than primary } \\
\text { education (<grade } 5)\end{array}$ & 10.89 & 2.606 & 0.009 & 2.69 & 19.09 & 1.02 \\
\hline & $\begin{array}{l}\text { Up to primary } \\
\text { education }\end{array}$ & -2.78 & -0.334 & 0.738 & -19.07 & 13.52 & 1.01 \\
\hline & From grade 5 to 11 & 0.97 & 0.749 & 0.454 & -1.57 & 3.50 & 1.17 \\
\hline & $\begin{array}{l}\text { Up to ordinary level } \\
\text { examination }\end{array}$ & -0.01 & -0.015 & 0.988 & -1.47 & 1.45 & 1.26 \\
\hline Number of Pregnancies & & -0.33 & -1.128 & 0.260 & -0.91 & 0.25 & 1.02 \\
\hline Number of weeks in pregnancy & & -0.09 & -0.884 & 0.377 & -0.30 & 0.12 & 1.01 \\
\hline $\begin{array}{l}\text { Used transport method to reach the health facility } \\
\text { (compared with using an own/family vehicle) }\end{array}$ & Public transport & 0.226 & 0.315 & 0.752 & -1.18 & 1.63 & 1.01 \\
\hline $\begin{array}{l}\text { Type of the health service used (compared with private } \\
\text { health facilities) }\end{array}$ & $\begin{array}{l}\text { Government health } \\
\text { facilities }^{*}\end{array}$ & -27.090 & -33.031 & 0.000 & -28.70 & -25.48 & 1.02 \\
\hline
\end{tabular}




\section{Discussion}

One primary reason for poor maternal and child health outcomes is identified as the higher OOPE associated with health care, especially among the poor, for whom health care access often imposes a considerable financial burden on families $[15,30,52]$. In this context, the present study aimed to comprehensively assess the OOPE of the first prenatal clinic visit-the "booking visit" in pregnancy care in Sri Lanka.

This study used a probability sample representing the whole district. The total OOPE estimated for the first prenatal clinic visit (USD 8.12) could be underestimated because the laboratory investigations for this cohort were provided free of charge by the RaPCo study. The examinations are offered through the free health care system in Sri Lanka. However, some pregnant women prefer attending paid services to minimize travel and the waiting time in public hospitals. Even with a probable underestimation, the OOPE was $4.5 \%$ of the total expenditure, and it is almost equal to the household health expenditure share, which was $4.7 \%$ in rural Sri Lanka [53]. This is a considerable amount compared to the population for a single clinic visit in the availability of free healthcare services, especially considering its impact on household income and expenditure. Evidence suggests that the OOPE of maternal healthcare can range between 1 and 5\% of total annual household expenditure throughout the pregnancy period and increase between 5 and $34 \%$ if complications occur. This could lead to a catastrophic expense for poor households in low-income countries in Asia and Africa [54].

The problem's severity is further emphasized with the reported $4 \%$ of OOPE of monthly household income within the lowest income quintiles. This could be challenging since only one mother was using health insurance for financing health care. Still, others had to withdraw from routine transactions/savings from informal loans with high-interest rates and selling assets. According to statistics, society's poorest section has to pay for health needs from their expenditure, which they keep for basic necessities [15, 16, 23, 30, 55, 56].

Most pregnant women $(79.2 \%)$ used government-free health services, and $61.3 \%$ of them were below the middle-income quintile. Similarly, the literature suggests that the free government healthcare facilities' usage rates, including inpatient, primary, and preventive care, were highest among the poor [57]. Even though using only government-free maternal health services, pregnant women had an OOPE of USD 3.49. Among them, onefifth was for the cost of medicine/micronutrient supplements (Folic acid, iron folate, Vitamin $\mathrm{C}$, and calcium supplementation), and the rest was for unavoidable direct non-medical costs. This study did not specifically collect facts regarding the reasons and types of medicine/micronutrient supplements that pregnant women purchased.

Nonetheless, the government prenatal health care services are provided micronutrient supplements and essential medicine for minor ailments free of charge. In that context, OOPE for the cost of medicine/micronutrient supplements indirectly implies either the unavailability of such medicine at the health care facility due to out-of-stock or pregnant women preferring to purchase them from outside due to various reasons. However, this is a vital issue since Sri Lanka exerts free government health services to all citizens $[39,43]$ and, primarily, the government-financed healthcare in Sri Lanka [58]. Therefore, the avoidable OOPE (direct medical cost) should be zero or at a minimal level in a setting with a free healthcare policy [10, 15, 24, 59-61]. However, available literature of different regions in the world also confirmed that the existence of OOPE with practicing public free health care policy and national-level free health programs in Nepal [1, 62-64], Bangladesh [1, 62, 65], and India [29, 35].

Among the study sample, $20.8 \%$ of pregnant women had utilized private health care services and had paid $42.1 \%$ of the cost for consultation and $21.6 \%$ for the cost for the medicine of the total OOPE. More importantly, $61.6 \%$ of pregnant women who used private health services were below the middle-income quintile. The emerging issue here is that (despite having free maternal healthcare services), many people spend high OOPE, unbearable for the low-income families' household expenses $[10,13,15,66-70]$. Instead of accessing free government health care, people tend to bear the actual cost of some drugs, investigations, and surgeries, which may place a significant burden on Sri Lanka's households $[39,71]$. This is under- and mal-utilization of the well-developed maternal health care package to catering all requirements for the initial prenatal clinic [49].

The positive correlation between OOPE and household expenditure is oblivious since OOPE acts as an independent health cost category, including medical and non-medical spending, which is in line with the existing evidence [72]. The number of pregnancies reported a negative association with OOPE; a study conducted in India revealed a similar association [36]. The probable reason could be better financial management during pregnancy with previous experience. Further, the middle-income category and educational level less than primary education was positively contributed high OOPE than others. The reason for the expenditure level of the middle-income group is due to the existing $5.9 \%$ of the total household expenditure, which was more than the rural Sri Lankan estimates [53]. In addition, the negative contribution on OOPE as using government-free maternal health services is evident since the Sri Lankan health sector is provided services free of charge. 


\section{Limitations}

The findings of the present study need to be understood with the following three limitations. First, the present study has a selection bias due to the lower response rate. Second, there may have a recall bias even though we collect data immediately after the first prenatal clinic visit. Third, OOPE estimation is underestimated since the RaPCo study provided laboratory and other investigations free of charge. It may be reduced the cost for laboratory and further investigations for mothers who were expected to use paid private health facilities.

\section{Conclusion and recommendations}

The study provides strong evidence that the reported OOPE of the first prenatal clinic visit is high since the OOPE share of total expenditure in a single event is almost equal to the rural Sri Lankan estimates. The direct medical cost is almost twice more elevated than the direct non-medical cost. A direct medical cost for medicines/micronutrient supplements is incurred by pregnant women who used only the government-free maternal health services. One-fifth of pregnant women utilize private health services despite having free maternal health services.

In this context, it is essential to ponder upon the implementation gaps in free health provision and create a mechanism to increase the utilization for governmentfree maternal health services to minimize the additional financial burden and further improve the maternal health care provision in Sri Lanka.

\section{Abbreviations}

OOPE: Out-of-pocket Expenditure; SDGs: Sustainable Development Goals; LMICs: Low and middle-income countries; RaPCo: Rajarata Pregnancy Cohort; USD: United States Dollar; MOH: Medical Officer of Health; PHM: Public Health Midwife; PHMM: Public Health Midviwes; POA: Period of amenorrhea; GA: Gestational Age; LKR: Sri Lankan Rupees; SD: Standard Deviation; IQR: Inter Quartile Range; MLRM: Multiple Linear Regression Model; AHEAD: Accelerating Higher Education Expansion and Development

\section{Acknowledgments}

Not Applicable.

\section{Authors' contributions}

SPG analyzed and prepared the original draft preparation. SPG, NDW, and SBW developed the methods used. NDW, IRP, TCA, and SBA developed conceptualization, supervised, and reviewed, and edited. TCA obtained the funding acquisition. All authors read and approved the final manuscript.

\section{Funding}

This research was supported by the Accelerating Higher Education Expansion and Development (AHEAD) Operation of the Ministry of Higher Education, Sri Lanka, funded by the World Bank. The funding agency has no role in the study's design, collection, analysis, interpretation of data, and manuscript writing. The grant number is DOR STEM HEMS [6026-LK 8743LK].

\section{Availability of data and materials}

The datasets used and/or analyzed during the current study are available from the corresponding author on reasonable request.

\section{Declarations}

\section{Ethics approval and consent to participate}

This study was conducted under the large cohort study in Anuradhapura District, Sri Lanka, Generating Evidence for Ending Preventable Maternal Deaths: the Rajarata Pregnancy Cohort (RaPCo). Ethical clearance to conduct the RaPCo study was obtained from the Ethics Review Committee of the Faculty of Medicine and Allied Sciences, Rajarata University of Sri Lanka (Reference no: ERC/2019/07). In accordance with the Declaration of Helsinki, all participants were informed that this study was voluntary and that data would be handled confidentially. All participants gave their informed written consent.

\section{Consent for publication}

Not applicable since individual data publication is not intended in this study.

\section{Competing interests}

The authors declare that they have no competing interests.

\section{Author details}

${ }^{1}$ Department of Community Medicine, Faculty of Medicine and Allied Sciences, Rajarata University of Sri Lanka, Saliyapura 50008, Sri Lanka. ${ }^{2}$ Department of Economics, Faculty of Social Sciences and Humanities, Rajarata University of Sri Lanka, Mihintale 50300, Sri Lanka.

Received: 13 May 2021 Accepted: 27 August 2021

Published online: 16 September 2021

\section{References}

1. Marc I, Roemer M. Out-of-Pocket Health Care Expenses for Medical Services, by Insurance Coverage, 2000-2014 [Internet]. 2017 [cited 2019 Oct 25]. Available from: https://meps.ahrq.gov/data_files/publications/st500/stat500. shtml

2. Mathauer I, Dale E, Jowett M, Kutzin J. Purchasing health services for universal health coverage: How to make it more strategic? World Health Organization; 2019. (Health Financing Policy Brief;6).

3. Essue BM, Kimman M, Svenstrup N, Kjoege L, Laba L, Hackett ML, et al. The effectiveness of interventions to reduce the household economic burden of illness and injury: a systematic review. Bull World Health Organ. 2015;93(2): 102-12. https://doi.org/10.2471/BLT.14.139287.

4. Sunny AK, Basnet O, Acharya A, Poudel P, Malqvist M, Kc A. Impact of free newborn care service package on out of pocket expenditure-evidence from a multicentric study in Nepal. BMC Health Serv Res. 2021;21(1):128. https:// doi.org/10.1186/s12913-021-06125-9.

5. World Bank Group. Colombia Systematic Country Diagnostic [Internet]. Systematic Country Diagnostic. 2015 [cited 2020 Nov 5]. p. 194. Available from: https://openknowledge.worldbank.org/handle/10986/23111?show= full\&locale-attribute=es

6. The World Bank. DataBank: Metadata Glossary [Internet]. Metadata Glossary of the World Bank - Indicator: Out-of-Pocket Health Expenditure, Code: SH. XPD.OOPC.ZS. 2020 [cited 2020 Oct 10]. Available from: https://databank. worldbank.org/metadataglossary/world-development-indicators/series/SH. XPD.OOPC.ZS

7. Gunarathne SP, Wickramasinghe ND, Agampodi TC, Prasanna IR, Agampodi SB. Economic burden of out-of-pocket expenditure, productivity cost during pregnancy and COVID-19 impact on household economy in a cohort of pregnant women in Anuradhapura District, Sri Lanka ; A study protocol version 1; peer review : awaiting peer revi. F1000Res. 2021;10(700):1-14. https://doi.org/10.12688/f1000research.53320.1.

8. Alvarez JL, Gil R, Hernández V, Gil A. Factors associated with maternal mortality in Sub-Saharan Africa : an ecological study. 2009;8(1):1-8. https:// doi.org/10.1186/1471-2458-9-462.

9. World Health Organization. Universal Health Coverage: A Commitment to Close the Gap [Internet]. London,United Kingdom; 2013. Available from: https://www.rockefellerfoundation.org/wp-content/uploads/uhc-close-thegap-report.pdf.

10. Leone T, James KS, Padmadas SS. The burden of maternal health care expenditure in India: multilevel analysis of national data. Matern Child Health J. 2013;17(9):1622-30. https://doi.org/10.1007/s10995-012-1174-9. 
11. Shen C, Williamson JB. Maternal mortality, women's s status, and economic dependency in less developed countries : a cross-national analysis. 1999; 49(2):197-214. https://doi.org/10.1016/S0277-9536(99)00112-4.

12. Muldoon KA, Galway LP, Nakajima M, Kanters S, Hogg RS, Bendavid E, et al. Health system determinants of infant, child and maternal mortality: a crosssectional study of UN member countries. Glob Health. 2011;7(1):42. https:// doi.org/10.1186/1744-8603-7-42.

13. Jo C. Cost-of-illness studies: concepts, scopes, and methods. Clin Mol Hepatol. 2014;20(4):327-37. https://doi.org/10.3350/cmh.2014.20.4.327.

14. Acharya J. Are free maternity services completely free of costs? Osong Public Heal Res Perspect [Internet]. 2016;7(1):26-31. Available from:. https:// doi.org/10.1016/j.phrp.2015.11.002.

15. Chandrakar A, Soni GP, Sinha AK, Jain K, Panda PS, Pradhan SK. Estimation of Out of Pocket Expenditure Under Janani Shishu Suraksha Karayakram ( JSSK ) in Rural Block of Chhattisgarh : A Community Based Cross-Sectional Study. Natl J Community Med. 2017;8(2):84-9.

16. Reichmann JP, Kirkbride MS. Nausea and vomiting of pregnancy: cost effective pharmacologic treatments. Manag Care. 2008;17(12):41-5.

17. Freeman DH, Gesler WM, Mieras BJ, Schymura M. A categorical data analysis of contacts with the family health clinic, Calabar. Nigeria Soc Sci Med. 1983; 17(9):571-8. https://doi.org/10.1016/0277-9536(83)90299-X.

18. Sauerborn R, Nougtara A, Diesfeld HJ. Low utilization of community health workers: results from a household interview survey in Burkina Faso. Soc Sci Med. 1989;29(10):1163-74. https://doi.org/10.1016/0277-9536(89)90359-6.

19. Yonder R. Are people willing and able to pay for health services? Soc Sci Med. 1989;29(0):35-42. https://doi.org/10.1016/0277-9536(89)90125-1.

20. Borghi J, Ensor T, Somanathan A, Lissner C, Mills A. Mobilising financial resources for maternal health. Matern Surviv. 2006;368(9545):1457-65. https://doi.org/10.1016/S0140-6736(06)69383-5.

21. Martines J, Vk P, Za B, Koblinsky M, Soucat A. Neonatal survival : a call for action. Neonatal Surviv. 2005;365(9465):1189-97. https://doi.org/10.1016/ S0140-6736(05)71882-1.

22. Bulatao RA, Ross JA. Which health services reduce maternal mortality? Evidence from ratings of maternal health services. Trophical Med Int Heal. 2003;8(8):710-21. https://doi.org/10.1046/j.1365-3156.2003.01083.x.

23. Van DE, O'Donnel O, Rannan ER, Somanathan A, Adhikari SE, Grag C. Catastrophic payments for health Care in Asia. Health Econ. 2007;16(11): 1159-84. https://doi.org/10.1002/hec.1209.

24. Onwujekwe OE, Uzochukwu BSC, Obikeze EN, Okoronkwo I, Ochonma OG, Onoka CA, et al. Investigating determinants of out-of-pocket spending and strategies for coping with payments for healthcare in Southeast Nigeria. BMC Health Serv Res. 2010;10(1). https://doi.org/10.1186/1472-6963-10-67.

25. Mohanty SK, Srivastava A. Out-of-pocket expenditure on institutional delivery in India. Health Policy Plan. 2013;28(3):247-62. https:/doi.org/10.1093/heapol/czs057.

26. Department of Census and Statistics SL. Status of Sustainable Development Goals Indicators in Sri Lanka: 2017. 2017.

27. World Health Organization (WHO). Health financing [Internet]. 2020. 2020 [cited 3 Feb 2020]. Available from: https://www.who.int/health_financing/ topics/financial-protection/monitoring-sdg/en/.

28. Goli S, Rammohan A, Moradhvaj. Out-of-pocket expenditure on maternity care for hospital births in Uttar Pradesh, India. Health Econ Rev. 2018;8(5):116. https://doi.org/10.1186/s13561-018-0189-3.

29. Sharma S, Verma PB, Viramgami AP, Vala MC, Lodhiya KK. Analysis of Out-ofPocket Expenditure in Utilization of Maternity Care Services in Urban Slums of Rajkot City, Gujarat. Indian J Community Med [Internet]. 2018;43(3):215-9 Available from: https://www.researchgate.net/publication/327882444.

30. Galtier-Dereure F, Boegner C, Bringer J. Obesity and pregnancy: complications and cost. Am J Clin Nutr. 2000;71(5 SUPPL):1242-8. https:// doi.org/10.1093/ajen/71.5.1242s.

31. Iles RA. Government doctor absenteeism and its effects on consumer demand in rural north India. Health Econ. 2019;28(4):475-91. https://doi. org/10.1002/hec.3858.

32. Lewis M. Informal payments and the financing of health care in developing and transition countries. Health Aff. 2007;26(4):984-97. https://doi.org/10.13 77/hlthaff.26.4.984

33. Binyaruka P, Balabanova D, Mckee M, Hutchinson E, Andreoni A, Ramesh M, et al. Supply-side factors influencing informal payment for healthcare services in Tanzania. 2021;36(7):1-9. https://doi.org/10.1093/heapol/czab034.

34. Stringhini S, Thomas S, Bidwell P, Mtui T, Mwisongo A. Human Resources for Health Understanding informal payments in health care: motivation of health workers in Tanzania. 2009;9(1):1-9. https://doi.org/10.1186/1478-4491-7-53.
35. Yadav J, John D, Menon GR, Allarakha S. Out-of-Pocket Payments for Delivery Care in India: Do Households face Hardship Financing ? J Health Manag. 2021;23(2):197-225. https://doi.org/10.1177/09720634211011552.

36. Rehman A, Adnan M, Mahmood H, Hassan M, Humayun A. Maternal health care expenditure among women in rural areas of Pakistan. Ann King Edward Med Univ. 2017;23(2):245-9.

37. Kaiser JL, McGlasson KL, Rockers PC, Fong RM, Ngoma T, Hamer DH, et al. Out-of-pocket expenditure for home and facility-based delivery among rural women in Zambia: a mixed-methods, cross-sectional study. Int J Women's Health. 2019;11:411-30. https://doi.org/10.2147/IJWH.S214081.

38. Dalinjong PA, Wang AY, Homer CSE. Has the free maternal health policy eliminated out of pocket payments for maternal health services? Views of women, health providers and insurance managers in Northern Ghana. PLoS One [Internet]. 2018;13(2):1-19. Available from. https://doi.org/10.1371/ journal.pone.0184830

39. de Silva A, Ranasinghe T, Abeykoon P. Universal health coverage and the health Sustainable Development Goal: achievements and challenges for Sri Lanka. WHO South-East Asia J Public Heal. 2016;5(2):82-8. https://doi.org/1 0.4103/2224-3151.206257.

40. Central Bank of Sri Lanka. Key Social Indicator: Central Bank Annual Report2019 [Internet]. Colombo; 2019. Available from: http://www.cbsl.gov.lk/pics n_docs/10_pub/_docs/efr/annual_report/AR2016/English/4_KSI.pdf

41. Smith O. Sri Lanka: Achieving Pro-Poor Universal Health Coverage without Health Financing Reforms. 2018;(38). Available from: https://openknowledge. worldbank.org/bitstream/handle/10986/29175/122814-WP-RDC-Sri-Lanka-ca se-study-pages-fixed-PUBLIC.pdf? sequence $=1$ \&isAllowed $=y$

42. World Health Organization. Regional Office for South-East Asia. Health financing profile 2017: Sri Lanka. World Health Organization. Regional Office for South-East Asia. 2017. https://apps.who.int/iris/handle/10665/259644 License: CC BY-NC-SA 3.0 IGO.

43. Da Cruz CS, Cecatti JG, Carroli G, Lumbiganon P, Hogue CJ, Mori R, et al. Obstetric transition in the World Health Organization multicountry survey on maternal and newborn health: exploring pathways for maternal mortality reduction. Rev Panam Salud Publica/Pan Am J Public Heal. 2015; 37(4-5):203-10.

44. Agampodi TC, Wickramasinghe ND, Prasanna RIR, Irangani MKL, Banda JMS, Jayathilake PMB, et al. The Rajarata pregnancy cohort (RaPCo): study protocol. BMC Pregnancy Childbirth. 2020;20(1):374. https://doi.org/10.1186/ s12884-020-03056-X.

45. Department of Census and Statistics of Sri Lanka. Household Income and Expenditure Survey 2016 Final Report [Internet]; 2018. p. 6. Available from: http://www.statistics.gov.Ik/HIES/HIES2016/HIES2016_FinalReport.pdf

46. Department of Census and Statistics - Sri Lanka. Census of Population and Housing 2012. ensus of Population and Housing. 2012.

47. Embassy of the Kingdom of the Netherlands. The Health Sector of Sri Lanka, vol. l; 2014. p. 1-50.

48. Institute for Health Policy of Sri Lanka. Data and Statistics [Internet]. 2020. 2020. [cited 2020 Jan 10]. Available from: http://www.ihp.lk/resources/data.html.

49. Family Health Bureau. Ministry of Health. Maternal Care Package: A Guide to Field Health Care Workers. 1st ed. Colombo: Family Health Bureau, Ministry of Health, Sri Lanka; 2011.

50. Investing.Com. USD/LKR - US Dollar Sri Lankan Rupee [Internet]. USD/LKR Historical Data. 2020 [cited 2020 Nov 5]. Available from: https://www. investing.com/currencies/usd-Ikr-historical-data

51. Knofczynski GT, Mundfrom D. Educational and Psychological Measurement for Prediction. Educ Psychol Meas [Internet]. 2008;20(10) Available from: http://epm.sagepub.com.

52. Unicef. The State of the World's Children 2009: Maternal and newborn health. Children. 2009:1-168. https://doi.org/10.18356/26b2aa25-en.

53. Central Bank of Sri Lanka. Sri Lanka Socio Economic Data 2020. Colombo, Sri Lanka, Statistics Department of Central Bank of Sri Lanka, Sri Lanka; 2020.

54. Brearley L, Mohamed S, Eriyagama V, Elawagedara R, Rannan-Eliya R. Out-ofpocket Spending on Maternal and Child Health in Asia and the Pacific: Impact of Maternal and Child Health Private Expenditure on Poverty and Inequity [Internet]. Vol. 35, Indian pediatrics. Colombo: Asian Development Bank; 2012. Available from: https://reliefweb.int/sites/reliefweb.int/files/resources/Impa ctofMaternaland ChildHealthPrivateExpenditureonPovertyandlnequity_0.pdf

55. Devadasan N, Criel B, Van Damme W, Ranson K, Van Der Stuyft P. Indian community health insurance schemes provide partial protection against catastrophic health expenditure. BMC Health Serv Res. 2007;7(1):1-11. https://doi.org/10.1186/1472-6963-7-43. 
56. Ellis RP, Alam M, Gupta I. Health Insurance in India: prognosis and prospectus. Econ Polit Wkly. 2000;35(4):207-17.

57. Ministry of Health \& World Health Organization. Public Health Success in Sri Lanka. 2016; Available from: http://www.searo.who.int/srilanka/documents/ policybriefsfinal.pdf?ua=1

58. Medicine $\mathrm{M}$ of health-nutrition and indigenous. Sri Lanka National Health Accounts 2013 [Internet]. 2013. Available from: http://www.health.gov.lk/ enWeb/publication/NHA/Sri Lanka National Health Accounts 2013.pdf.

59. Kerketta S. Out of pocket expenditure on utilization of ante-natal and delivery care services in India: analysis based on NSSO 60th round. Int J Reprod Contraception, Obstet Gynecol. 2015;4(6):1704-9. https://doi.org/1 0.18203/2320-1770.ijrcog20151126.

60. Issac A, Chatterjee S, Srivastava A, Bhattacharyya S. Out of pocket expenditure to deliver at public health facilities in India: a cross sectional analysis. Reprod Health [Internet]. 2016;13(1):1-9. Available from:. https://doi. org/10.1186/s12978-016-0221-1.

61. Akalu T, Guda A, Tamiru M, Mariam DH. Examining out of pocket payments for maternal health in rural Ethiopia: Paradox of free health care unaffordability. Ethiop J Heal Dev. 2012;26(Specialissue1):251-7.

62. Roemer MI. Out-of-Pocket Health Care Expenses for Medical Services, by Insurance Coverage, 2000-2014: Statistical Brief (Medical Expenditure Panel Survey (US)); 2001. Available from: http://www.ncbi.nlm.nih.gov/pubmed/2 8783273.

63. Simkhada P, E van T, Sharma G, Simkhada B, John T. User costs and informal payments for care in the largest maternity hospital in Kathmandu, Nepal. Heal Sci J. 2012;6(2):317-34

64. Borghi J, Ensor T, Neupane BD, Tiwari S. Financial implications of skilled attendance at delivery in Nepal. Trop Med Int Heal. 2006;11(2):228-37. https://doi.org/10.1111/j.1365-3156.2005.01546.x.

65. Khan SH. Free does not mean affordable: maternity patient expenditures in a public hospital in Bangladesh. Cost Eff Resour Alloc. 2005;3(1):1-7. https:// doi.org/10.1186/1478-7547-3-1.

66. Perkins M, Brazier E, Themmen E, Bassane B, Diallo D, Mutunga A, et al. Outof-pocket costs for facility-based maternity care in three African countries. Health Policy Plan. 2009;24(4):289-300. https://doi.org/10.1093/heapol/ czp013.

67. Afsana K. The tremendous cost of seeking hospital obstetric care in Bangladesh. Reprod Health Matters. 2004;12(24):171-80. https://doi.org/10.1 016/50968-8080(04)24142-8.

68. O'Donnell O, van Doorslaer E, Rannan-Eliya RP, Somanathan A, Adhikari SR, Akkazieva B, et al. Who pays for health care in Asia? J Health Econ. 2008; 27(2):460-75. https://doi.org/10.1016/j.jhealeco.2007.08.005.

69. Nahar S, Costello A. The hidden cost of "free" maternity care in Dhaka, Bangladesh. Health Policy Plan. 1998;13(4):417-22. https://doi.org/10.1093/ heapol/13.4.417.

70. Khan R, Blum LS, Sultana M, Bilkis S, Koblinsky M. An examination of women experiencing obstetric complications requiring emergency care: perceptions and sociocultural consequences of caesarean sections in Bangladesh. J Health Popul Nutr. 2012;30(2):159-71. https://doi.org/10.3329/jhpn.v30i2.113 09.

71. Sørensen JB, Konradsen F, Agampodi SB. Can the success of primary health Care in Sri Lanka be maintained? Anuradhapura Med J. 2018;11(1):1. https:// doi.org/10.4038/amj.v11i1.7645.

72. Ministry of Health. National Family Planning programme review 2016 Sri Lanka 2017.

\section{Publisher's Note}

Springer Nature remains neutral with regard to jurisdictional claims in published maps and institutional affiliations.

Ready to submit your research? Choose BMC and benefit from:

- fast, convenient online submission

- thorough peer review by experienced researchers in your field

- rapid publication on acceptance

- support for research data, including large and complex data types

- gold Open Access which fosters wider collaboration and increased citations

- maximum visibility for your research: over $100 \mathrm{M}$ website views per year

At $\mathrm{BMC}$, research is always in progress.

Learn more biomedcentral.com/submissions 